\title{
Beyond Mount Kenya Region: 40 Years of Theological and Practical Education at St Andrew's College, Kabare (1977-2017), by Julius Gathogo
}

Evangel Publishing House. 2017. Nairobi, pp. 250

ISBN: 9789966202925

\section{Reviewed by: Joyce Karuri}

https://orcid.org/0000-0001-5657-3703

Anglican Church of Kenya

joycegkaruri@gmail.com

A people whose history is not known to them remain befogged, and their vision for the future is curtailed (page $\mathrm{x}$ ).

In this book, Professor Julius Gathogo immortalises for posterity the story of Kabari (anglicised as "Kabare"), which means "a steep" or "a hill”; a place with a rich history of Christian mission in its varied forms, spanning more than a century.

As much as its primary intention is the celebration of 40 years of the existence of $\mathrm{St}$ Andrew's Bible College (1977-2017), the book narrates the humble beginnings of Kabare as the oldest CMS (Church Missionary Society) mission centre in the Gichugu zone of Kirinyaga District. Oozing with deep mission history, Kabare was like a Mt Zion of sorts for decades; many octogenarian Anglicans of Gichugu remembering it as the hallowed place where they walked tens of miles to be baptised, confirmed, taught catechism and even wedded.

As the Anglican Church in Mt Kenya region continued to grow, Kabare was clearly the perfect place to put up a training institute for clergy of the newly created Diocese of Mt Kenya East (1975) and beyond, as it turned out. In this book, Dr Gathogo vividly brings onto the scene the visionary and vibrant leadership of the first bishop of Mt Kenya East, the then youthful Bishop David Gitari who later rose to become the 3rd archbishop of the Anglican Church of Kenya. We get to see how his leadership transformed Kabare into an internationally famed centre that not only trained clergy from (and for) Mt Kenya East Diocese, but also beyond; further attracting mission partners from around the globe, both as trainers, development practitioners, and consultative partners, all in a bid to put the diocese on a four-dimensional model of growth as exemplified in Luke 2:52, which was his favourite development-driving scripture.

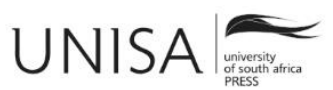




\section{Karuri}

Indeed, as John Maxwell commonly observes: "Everything rises and falls on leadership," and in Kikuyu we say, iguthua ndongoria itikinyagira nyeki (when the leader limps, everyone starves). The book largely testifies to the impact of intellectual leadership of Bishop David Gitari. Upon his consecration at the young age of 37, he set out to serve on the mandate of his consecration, executing the integral mission of the church, to feed the soul, the mind, the body and the social being. This integral approach to mission eventuated the transition of the college name from Kabare Bible School to St Andrew's College of Theology and Development. The college has had students from across the national ethnic terrain, and also from countries like Sudan, Southern Sudan, the DRC, Tanzania, and Rwanda, while others came on exchange programmes from overseas. What had initially begun as a Diocesan Bible School, soon shattered the restricting boundaries to become a home far away from home, for many, including Sudanese refugees.

The distinctiveness of the college was acclaimed in 1991 and 1998 respectively by subsequent commissions that were tasked to study the viability of the theological colleges of the Anglican Church of Kenya.

It has been said — with a jesty twitch though — that life begins at 40 . We can postulate on the basis of this, that St Andrew's at 40 can only get better, climbing upwards to upper echelons of achievement; building from where others reached. Nevertheless, as with all growth, a smooth run is never assured, as progress is always marked with bumps and dents. In project planning and management, we are always cautioned on the need for continuous monitoring and evaluation, for purposes of staying focused and on course. The author observes that since the mother diocese that conceived the institute was subdivided into five autonomous dioceses, issues of ownership of the college may not have been resolved with finesse, at least according to a former principal, Gideon Ireri, who said in part:

I and Archbishop Gitari wanted it to become a university in 1988. Although the idea was to have it owned by the Province, it also appears that it is owned by the former dioceses of Mt Kenya East. ... Let it begin as a campus of the proposed Anglican university. One day, it may become an autonomous university. ... The events that have taken place have shown that its ownership can be complicated (page 75).

In his analysis of events, the author has thus given us a peep into a seemingly glaring lacuna that can present fertile breeding ground for serious future dispute, as you never know the kind of church leaders that will spring up. "A new Pharaoh may arise, who knows not Joseph." Meanwhile, rather than becoming embroiled in an ownership issue that has no sudden answer, Dr Gathogo thinks greater urgency is the need for St Andrew's:

... to lead the parade in ushering apt theology and philosophy that will offer social transformation for the benefit of Mt Kenya region and beyond ... the real deal is the 


\section{Karuri}

content. ... Does it lead the students to become critical and creative thinkers? ... How relevant and how market-driven is the nature and content of education? (page 75-76).

The author further throws a challenge to the college leadership to take advantage of the varied, glaring opportunities that the new age presents in terms of advancement in information technology — or else it gets rendered moribund. Days are past when theological training was taught only in a theological institute; today one can get a theological degree even from a secular institute and public university. Hence, churchrelated colleges must up their game, rise to the occasion and compete reasonably with other players in what he refers to as "the market place." Online learning, zoom lessons, video conferencing and other virtual forms of learning are models that the college must embrace for purposes of boosting relevance and competence. The author further recommends for the teaching fraternity to form Professional Learning Communities (PLCs) for purposes of mentoring and coaching one another, and essentially linking up with such other bodies around the globe, for indeed the impact of St Andrew's college is beyond the Mt Kenya region.

The author comprehensively tackles the gender inclusivity factor in the growth of the college and notes regretfully the long journey women students have had to undertake to occupy equal space among their male counterparts. Women have had to contend with great odds ranging from subordination to male clergy in the parishes, lower salary scales, and lower ranks - even when they were better in class than their male colleagues. To date, this misogynistic tendency persists and women have had to rise against the endemic tide to claim their place among achievers. The author points out women like Dr Lydia Mwaniki, now serving at the AACC; Rev. Pauline Wanjiru of EHAIA-WCC; Rev. Major Jane Wairimu Muringi, a chaplain with Kenya Defence Forces; and the late Rev. Mary Njeri, among others, all of whom were theologically cradled at St Andrew's college. For all these and their numerous young mentees, Aluta Continua.

Of special interest is the role played by the East African Revival movement on the moral and spiritual grounding of the students early on. The college programme had a day for revival fellowship, which was often held at the old church whose reading font had a carved inscription in Luganda, Kigambo kya Katonda, meaning "The Word of God." One will recall that Uganda was key in fanning the East African Revival fire, and even gave the trademark revival hymn Tukutendereza Yesu (Glory Yes Hallelujah), which continues to punctuate revival fellowships and conferences to date.

Beyond Mount Kenya Region is a power-packed attempt to compress so much history in one handy package for easy reference by all who care to study the history of the integral mission centre on the hill, Kabare; and in the end find that they have gotten more than they bargained for.

Biblically, the number " 40 " appears to be used severally, figuratively, and though it is not my intention to read more than is intended, it may not be a far-fetched idea to suggest 
that this book be read with that figurative hindsight, evaluating the 40 years with critical retrospection, and considering improvements that could go well with the apparent generational rebirth, if Judges 32:13 is worth the reflection. By citing the Kikuyu saying wathi wakura wongagirira ungi (when an idea outlives its usefulness it gives way to other ideas), the author also contends that Giikaro kimwe ki ndaa, (stagnation breeds mouldiness). It is in this spirit that he appears to speak the truth in love, urging St Andrew's College to study, appreciate and move along with the changing times.

Every chapter in this book starts with a historical analysis and ends with a conclusion that sums up the analysis and further blends with the author's overall views. This makes the book interesting to read in spite of the numerous historical details and data that many a reader may find fatiguing.

I highly recommend this book to all lovers of history, St Andrew's alumni, all theological institutions and to the Christians of Mt Kenya region and beyond. It is a treasure to all who may wish to research about St Andrew's College or/and the various related themes. 